\title{
The Spirituality of the Laity in the Diocese of Bacolod: Basis for the Development Program
}

\author{
Giovanni A. Solibio, $\mathrm{PhD}$ \\ ${ }^{1}$ University of St. La Salle- Bacolod City, Philippines
}

\begin{abstract}
The main purpose of this research is to conduct an in-depth assessment of the participation of the laity on threefold function of Christ shared during baptism namely priestly, prophetic, and kingly as basis for the development program in the Diocese of Bacolod. The study also sought to examine and analyze the significant difference of the level of participation of the laity on threefold function. The study used descriptive research methodology utilizing survey questionnaire and focus group discussion using interview guides. Purposive sampling procedure was used to 500 targeted lay respondents and stratified sampling was used to determine the targeted parishes namely Our lady of Victory Parish-Victorias, Our lady of Lourdes Parish-Bata, San Antonio Abad Parish- Taculing, St. John Nepomuceno Parish-Sum-ag, and St John the Baptist Parish-Bago. A researcher-made questionnaire was utilized to gather data from the respondents. The level of participation on threefold function was determined by using the Spirituality Development Index labeled 3.50-4.00 as mature/practiced, 2.50-3.49 as experienced, 1.50-2.49 as developing, 1.00-1.49 as beginning, A scale of 1-4, with 4 as the highest and 1 as the lowest, determined the participation level on threefold functions provided to the respondents. The assessment of the level of participation of the laity on threefold function revealed that the participants are labeled as experienced level in priestly function with a mean of 3.03, in prophetic function with a mean of 2.85, and in kingly function with a mean of 2.50 which means they practiced the threefold mission in moderate levels. Identified strengths have to be enhanced and needs have to be addressed. Results also showed that across profession priestly function $\rho$-value(.00038) is less than $\alpha(0.5)$, prophetic function $\rho$-value (.018) is less than $\alpha(0.5)$ and kingly function $\rho$-value(.004) is less than $\alpha(0.05)$ which show that there is a significant difference. Moreover, in the level of involvement priestly function $\rho$ value $(3.89 \times 10-17)$, prophetic function $\rho$ value (1.75 $\times 10-17)$, kingly function $\rho$-value (1.83 $\times 10$-15) are all less than

$\alpha(0.05)$ which show that there is a significant difference. In the parish location, priestly function $\rho$-value (4.31 $x$ 10 -13), prophetic function $\rho$-value $(1.03 \times 10-8)$, kingly function $\rho$-value $\quad(2.52 \times 10-12)$ are all less than $\alpha$ (0.05) which show that there is a significant differences in the level of participation in each threefold function. Moreover, there is a significant relationship between the priestly and prophetic function since $\rho$-value $(<0.00001)$ is less than $\alpha(0.05)$, between the priestly and kingly function since $\rho$-value $(<0.00001)$ is less than $\alpha(0.05)$ and between the prophetic and kingly function since $\rho$-value $(<0.00001)$ is less than $\alpha(0.05)$. Participants also revealed that performing the priestly, prophetic and kingly functions eventually made them as mature, more committed, dedicated, and obedient disciples of Christ. The study suggested that relevant and comprehensive programs must be adopted in the Diocese to reach mature spirituality among the laity.
\end{abstract}

Keywords: Laity, spirituality, priestly, kingly, prophetic

\section{Introduction}

The identity of the lay faithful is born in and nourished by the sacraments of Baptism, Confirmation and the Eucharist. Baptism conforms the person to Christ, son of the Father, first-born of every creature, sent to all as Teachers and Redeemer.(Compendium of the Social Doctrine of the Church, para.11,2004)

Moreover, the Compendium discusses the lay catholics are disciples of Christ starting with the sacraments, that is, by virtue of what God has wrought in them, marking them with the very image of his son Jesus Christ. It is from this divine gift of grace, and not from human concession, that is born the threefold "munus"(gift or duty) that characterizes the lay person as prophet, priest and king according to his secular nature.

The laity moreover is secular in nature." They live in the world, that is, in each and in all of the secular professions and occupations. They live in the ordinary circumstances of family and social life from which the very web of their existence is woven"(Lumen Gentium 31). 
Hence, the laity has special tasks to do as baptized Christian and disciple of Christ. And, how will he perform such functions as priest, prophet and king in his secular occupations?

The church directs the laity on how to live the threefold function.

The Dogmatic Constitution (2006) describes " for all their works, prayers, and apostolic undertakings, family and married life, daily work, relaxation of mind and body, if they are accomplished in the Spirit indeed even the hardships of life if patiently born all these become spiritual sacrifices acceptable to God through Jesus Christ. And so, worshipping everywhere by their holy actions, the laity consecrate the world itself to God, everywhere offering worship by the holiness of their lives"(LG34)

The laity also fulfills their prophetic mission by evangelization," that is, the proclamation of Christ by word and the testimony of life."(LG 35)

Moreover, the laity performs the kingly function" whenever we are able to overcome sin in ourselves and in the environment and allow the grace of God to break through into the world, then we exercise our share in the kingship of Christ."(LG 36)

As a laity, what is our way of life where we are involved like in the factories, schools, in corporate world, in the farm and sea, in the government offices and even in the side streets or public markets? Do they conform to the will of God? Do they respond to the call of priestly, prophetical, and kingly mission? Who come to influence and assist in the fulfillment of these missions? And where will the exercise of these functions be tangible, nourished and developed?

So, it is in this perspective that the researcher is motivated to conduct this study on the spirituality of the laity in the Diocese of Bacolod. The researcher is hopeful that through this the threefold mission of the laity will be unveiled and revisited at once, and it will be given attention and consideration by the pastors and lay leaders. May this be God`s instrument for the laity to grow and nourish their spirituality as they collaboratively respond to the challenge of becoming living witnesses of Christ`s love and presence to the world and of building God`s kingdom in it.

\subsection{Statement of the Problem}

The purpose of the study is to conduct an assessment of the spirituality of the laity based on the threefold function of Christ namely priestly, prophetic and kingly shared through the sacrament of Baptism and to provide basis in designing a development program.

\subsection{Conceptual framework of the Study}

This study is rooted on the baptismal character of the Christians as they share in the priestly, prophetic, and kingly functions of Christ.

According to the Dogmatic Constitution, Lumen Gentium 10(2006), all baptized Christians share in the priestly dignity of Christ. Likewise, we share in the prophetic mission by witnessing to Christ in our lives through a life of faith and charity and by offering to God a sacrifice of praise. And we share in His kingship whenever we order creation to the praise of God. To be king is to minister, to serve.(LG 36)

\section{Methodology}

\subsection{Research Design}

The method used in this study is a descriptive research utilizing the researcher-made survey questionnaire and focus group discussion using interview guide.

The respondents of the study were classified in three categories namely profession, ;local church involvement, and parish location. Out of the 500 respondents, the Focus Group Discussion had 36 participants who came from the selected parishes. 


\subsection{Sampling Procedure}

From the 1, 073,662 Catholics in the Diocese of Bacolod, 500 respondents were chosen for this study, During the survey, the researcher used the stratified sampling procedure to intently identify the five parishes by reason of geographical representation that is northern, central, and Southern portion of the Diocese.

\subsection{Research Instrument}

The researcher instrument in this study was a researcher-made questionnaire on the threefold functions of Christ shared by every baptized Christian namely: priestly, prophetic and kingly. It is entitled Threefold Functions-Based Spirituality Assessment Tool consisting of 110 items with three(3) domains and nine(9) strands describing behavioral attributes of the priestly, prophetic, and kingly functions of Christ.

\subsection{Validity and Reliability of the Instrument}

The researcher-made questionnaire was subjected to both content and face validation process and presented to professors and experts in the field of study who gave their critical comments and suggestions.

Chronbach Alpha statistical measure was used with its coefficient of 0.05 . Result showed an alpha value of 0.982 which indicates high reliability of the instrument.

\subsection{Statistical and Qualitative Treatment of Data}

Quantitatively, the data were treated using the most appropriate statistical tools and qualitatively, the data were organized and analyzed.

\section{Results And Discussion}

\subsection{The socio-demographic profile of the respondents}

From the total of 500 respondents, 179 or $35.80 \%$ is male and 321 0r $64.20 \%$ is female respondents. There are more participation and involvement of female laity as compared to male laity. The result significantly shows also that majority of the respondents are married couples 241 or $48.20 \%$, mothers 185 or $37 \%$, and between 13 39 years old 217 or $43.4 \%$, with bachelor`s degree 162 or $32.40 \%$, parish 100 or $20 \%$.

\subsection{The Level of Participation of the Laity on Threefold Functions of Christ}

\begin{tabular}{lcc}
\multicolumn{3}{c}{ TABLE I: The Mean Level of Participation as a Whole } \\
\hline Functionsn & Mean & Interpretation \\
Priestly & 3.03 & Experienced \\
Prophetic 500 & 2.85 & Experienced \\
Kingly & 2.50 & Experienced \\
\hline
\end{tabular}

This implies that the laity has practiced the threefold function in their lives at moderate levels. There are some identified practices that are considered to be strengths. They have been enriched in the family, groups, peers and in the parish. These are evident in the programs being undertaken by the parish and Diocese like Lenten recollection and confession, devotional novenas, school and parish catechesis, family day celebration, feeding and medical missions, and continuing Basic Ecclesial Communities formations and trainings. It is further noted that the level of participation of the laity on threefold functions vary. The laity has a higher participation level on priestly function compared to prophetic and kingly. It can be drawn in the result that kingly function has the lowest mean. This implies that the laity`s practices towards serving the neighbor particularly the poor still needs to be encouraged and developed. On the other hand, the priestly function implies that spiritual development on this mission is given priority and enrichment. This also shows that they are continuously offering themselves and daily activities to God in the celebration of the Eucharist. This means that their works, prayers and apostolic endeavors, their ordinary married and family life, their daily labor, their mental and physical relaxation are carried out in the Spirit. All of these become spiritual sacrifices acceptable to God through Jesus Christ (1Pt.2:5). Result also confirms that the laity understands the meaning of the "Eucharist" thus, they participate fully, consciously and actively. Likewise, they also recognize the essentials of sacraments in their lives. 
The result also shows that through their participation in the prophetic mission of Christ. " which is to proclaim the kingdom of his Father by the testimony of his life and by power of his word, the lay faithful are responsible to accept the gospel in faith and to proclaim it in word and in deed, without hesitating to courageously identify and denounce evil. Likewise, it signifies that the laity has been proclaiming and witnessing Jesus to their respective family, workplace, parish, or Basic Ecclesial Communities or wherever they are with courage and happiness despite of its consequence like despise, division and condemnation.

\subsection{The Relationship between the Levels of Participation of the Laity on Threefold Functions namely: Priestly and Prophetic, Priestly and Kingly and Prophetic and Kingly.}

Table 2 shows the relationship in the participation of the laity between the priestly and prophetic functions. It is noted that $\mathrm{r}$ is 0.91 . Based on Pearson $\mathrm{r}$ Correlation Scale, there is a very strong positive linear relationship. The $\mathrm{p}$ value $(<0.00001)$ is less than $\alpha(0.05)$. Therefore, relationship is statistically significant. Hypothesis is rejected.

TABLE II: Comparison of the Relationship in the Level of Participation of the laity Functions: Priestly and Prophetic-

\begin{tabular}{|c|c|c|c|c|c|c|}
\hline Function & $\mathrm{N}$ & Mean & $\alpha$ & $\mathrm{r}$ & $\mathrm{p}$ value & Interpretation \\
\hline Priestly & 500 & 3.03 & 0.05 & 0.91 & $<0.00001$ & $\begin{array}{l}\text { Relationship is } \\
\text { statistically }\end{array}$ \\
\hline Prophetic & 500 & 2.85 & & & & significant \\
\hline
\end{tabular}

Based on the strength relationship scale, there is a high relationship between the priestly and prophetic functions. It means that the participation of the laity on priestly functions has a very linear relationship with the prophetic functions. This means that the level of participation on priestly function and prophetic function is highly significant with the laity respondents in five parishes. This shows that the laity`s value for prayer and sacraments, authentic attitude of worship, love of God and neighbor, active participation in the liturgy have significant effect to their prophetic tasks of proclamation of the gospel by word and deeds. This is supported by the result of FGD when the participants shared that through bible reading, rosary, prayer and worship activities, we become more committed our mission Gathering children for a dialogue (parenting and counseling), sharing, and life of integrity are learned through daily bible reading. It can be noted that prayer life indeed is the foundation of moral dimension of the laity. Then, the fruit of our prayer life is seen in our witnessing.

Table 3 shows the relationship in the participation of the laity between the priestly and kingly functions. It is noted that $r$ is 0.79 . Based on the Pearson $r$ Correlation Scale, there is a very strong positive linear relationship. The $\mathrm{p}$ value $(<0.00001)$ is less than $\alpha(0.05)$. Therefore, relationship is statistically significant. Hypothesis is rejected.

\begin{tabular}{|c|c|c|c|c|c|c|}
\hline \multirow{3}{*}{$\begin{array}{l}\text { Function } \\
\text { Priestly }\end{array}$} & \multirow{2}{*}{$\begin{array}{l}\mathrm{N} \\
500\end{array}$} & \multirow{2}{*}{$\begin{array}{l}\text { Mean } \\
3.03\end{array}$} & $\alpha$ & $\mathrm{r}$ & \multirow{3}{*}{$\begin{array}{l}\mathrm{p} \text { value } \\
<0.00001\end{array}$} & \multirow{3}{*}{$\begin{array}{l}\text { Interpretation } \\
\text { Relationship is } \\
\text { significant }\end{array}$} \\
\hline & & & & & & \\
\hline & 500 & 2.50 & 0.05 & 0.79 & & \\
\hline
\end{tabular}

There is a high relationship between the priestly and kingly functions. It implies that the participation of the laity on priestly function has a very strong linear relationship with the kingly function. This means that the level of participation on priestly function and kingly function is highly significant with the laity respondents in five parishes.

This means that the laity`s value for prayer and sacraments, authentic attitude of worship, love of God and neighbor and active participation in the liturgy have significant effect to their kingly tasks of making themselves as a gift to others by serving them in justice and in charity in the Basic ecclesial Community or wherever they may be.

This is supported by the result of FGD when the participants mentioned that "If I attend mass, I am generous in financial and time. I love to serve, and I am happy doing it for others and I am empowered to care them.". 
Therefore, we can say that the true measure of our prayer life is on how we love and serve the poor people of God in our community. Thus our actions speak how deep our relationship with God.

Table 4 shows the relationship in the participation of the laity between the prophetic and kingly functions. It is noted that $r$ is 0.8 . based on the Pearson $r$ Correlation Scale, there is a very strong positive linear relationship. The $\mathrm{p}$ value $(<.00001)$ is less than $\alpha(0.05)$. Therefore, relationship is statistically significant. Hypothesis is rejected.

TABLE IV: Comparison of the Relationship in the Level of participation of the laity Functions:

\begin{tabular}{|c|c|c|c|c|c|c|}
\hline Function & $\mathrm{N}$ & & & & & Internretation \\
\hline Prophetic & 500 & 2.85 & & & & Relationship is \\
\hline Kingly & 500 & 2.50 & 0.05 & 0.8 & $<0.00001$ & $\begin{array}{l}\text { statistically } \\
\text { significant }\end{array}$ \\
\hline
\end{tabular}

There is a high relationship between the prophetic and kingly functions. It implies that the participation of the laity in prophetic functions has a very strong linear relationship with the kingly functions. This means that the laity`s prophetic tasks of proclamation of the Gospel by word and deeds like preaching Christ and His teachings have significant effect to their kingly tasks of making themselves as a gift to others by serving them in justice and in charity in the Basic Ecclesial Communities.

Therefore, generally, the result of this study shows the affirmation of the following statement of the Catholic Bishops Conference of the Philippines 2013: " There is no Christianity without love. There is no love without justice. There is no integral proclamation of Christianity without effective action for justice."

\section{Conclusions}

The level of Spirituality of the laity in the Diocese of Bacolod on threefold functions namely: priestly, prophetic and kingly have reached experienced or moderate level. There are items that are identified as strengths and others are labeled as weaknesses that need to be developed. The BEC then had been active in developing programs that enriched the spirituality of the laity. Pastors and lay leaders have extended effort in some extent.

However, there are still other items of function that need to be addressed especially on kingly mission. Though the social action office provided programs to facilitate its development, the implementation is not massive. Much must have done to achieve mature level of participation.

The laity has greater participation in Eucharistic life and worship activities but not in charity and justice which required witnessing of Christian faith. Least priority was given to this function (kingly) in the basic ecclesial communities since it requires time and resources.

Eucharistic life affects prophetic tasks and love for others. The fruit of prayer life is seen in daily witnessingby words and in deeds.

Parish has distinct and unique level of participation on spiritual development of the laity.

Priest, kapilyan or lay leaders and families significantly contribute to the development of spirituality.

The Church then is constantly nurturing and progressively putting her effort on developing the spirituality of the laity on threefold functions-priestly, prophetic and kingly.

\section{Recommendations}

Based on the findings of this study, the researcher gives the following recommendations:

- Intensive campaign on conscious, active, and full participation in the liturgical celebration in the parishes.

- Establish a Spirituality Center for the laity

- Integrate prayer life in the public offices and schools

- Intensify the parish and school catechesis by providing skills and trainings using the new evangelization scheme 
- Propose a mobile interactive evangelization scheme by linking with the support group like professionals and businessmen.

- Intensify the functionality of mass media to effect new evangelization

- Intensify awareness campaign program among the youth and non- professional to encourage more volunteers in various ministries of the church

Organize and form the laity from different occupations using their respective charisms.

\section{Acknowledgements}

The researcher expresses his profound gratitude to all those who extended their prayers and support for the completion of this paper.

To Msgr. Louie Galbines, his dissertation adviser whose motivation and encouragement inspired the researcher to conduct this study. To his panel of evaluators: Fr. Nitodel Soriano, PhD., Dr. Irma Madonna Echaus, Dr. Felicidad Altalaguire, Dr. Jay Estrellas, and Dr. Ronie Lizada.

To his friend, Dr. Noel Maranon and to his support staff.

To the Vicar Foranes, Rev.Fr. Jose Rey Erexima, Rev. Fr. Farley Ray Santillan, Rev. Fr. Noli Blancaflor, Rev. Fr. Anecito Buenafe, and Fr. Boy Tan and the basic ecclesial coordinators for their warmth accommodation and cooperation in the conduct of this study in their respective parishes.

To the juror and expert validators of the instrument who extended their time freely and assisted generously the researcher in the completion of the instrument.

To the chancery office and commission on youth of the diocese of Bacolod which provided the researcher with necessary data, references and related documents.

To his friends, parent, family members, and colleagues in school. Your moral and financial support are deeply appreciated.

To the intercession of the Our lady of Lourdes whose love and care are always providential. To St. Lorenzo Ruiz of manila, san Pedro Calungsod, St. John Mary Vianney, and St. John Paul II, for their protection and guidance.

This humble masterpiece is for the greater glory of God.

\section{References}

[1] Catechism of the Catholic Church (2003).www.vatican.va/archive/ENG0015/INDEX.HTM Libreria Editrice Vaticana

[2] Compendium of the Social Doctrine of the Church, Manila: Word \& Life Publications. Pp.333-335

[3] Commission Reports(2009). On Pastoral and Evangelical Reports.pp 1-20.Available:dominicderramas@ yahoo.com,

[4] M. Cuaycong, "Catholic Faith Life Practices of la Sallian students and their parents: Basis for Formation Program, Graduate School of Management, University of St. La Salle, Bacolod City, Philippines, 2014.

[5] Gray, M \& Pearl, P.Sacraments today, belief and practice among U.S. Catholics(2008), CARA,20.http://www.usech.org/beliefs-and- teachings/how-we-teach/new-evangelization/retrieved on 2013 April

[6] Jinsun Yong,J.Kim, J.Park,J.Seo,I \& Swinton,J.(2011). Effects of a Spirituality training program on the spiritual and psychosocial well-being of hospital middle manager nurses in Korea.The Journal of Continuing Education in Nursing,42(6)280-288

https://doi.org/10.3928/00220124-20101201-04

[7] Maranon, Noel S.(2011). Redefining the sunset years: the lived experiences of retired university educators in bridge employment. Dissertation Graduate School of Management. University of St. La Salle, Bacolod City, Negros Occidental Philippines. 
[8] Picardal, A.(2014) The basic ecclesial communitiesin the Philippines.Recent Development and Trends Report. Manila

[9] Po, S.(2009). Kuching Archdiocesan Youth Apostolate(KAYA), Malaysia. Laity,pp.4-5

[10] Second Diocesan Synod, Acts and Decrees(2005)Bacolod,pp.156-158

[11] Second Plenary Council of the Philippines, Acts and Decrees (1992). Intramuros, manila, Philippines: catholic Bishop`s Conference of the Philippines.pp245-251

[12] Second Vatican Council, Dogmatic Constitution on the Church Lumen Gentium (2006) pp. 766-798

[13] Smith, J.G.(2007). Spirituality in the Salesperson: The impact of the golden rule and personal faith on workplace job attitudes: Published Doctoral Dissertation, University of St. La sale, Bacolod City, Philippines

[14] Soriano, N.(2011). Enhancement of the Social Services program through collaboration between the Department and Social Action Center. Dissertation. Graduate School Management, University of St. La Salle, Bacolod City, Philippines

[15] Tyson, John R.(1999). Invitation to Christian Spirituality. An Ecumenical Anthology. New York: Oxford University Press.

[16] World Youth Day in Brazil.(2013).http:www.huffingtonpost.com/2013/07/28pope-francis-world-youthdaymass_n_3667321.html. retrieved on 2013 April from the World Wide Web. 